\title{
DIALOGANDO COM O PROFESSOR VILSON LEFFA
}

\section{Diógenes Cândido de Lima}

(Org.)

Entrevistadores:

Ana Claudia Oliveira Azevedo

Jamilly da Silva Oliveira

João Pedro Santana Luciano da Silva

Lucas Viana Alencar

Marcus Avelar Baleeiro do Rosário

Rossana Oliveira Reis

\section{Introdução}

Diógenes Cândido de Lima: A disciplina de Linguística Aplicada (LA) ao Ensino de Língua Estrangeira é ofertada, uma única vez ao ano, para os alunos de Letras Modernas, do Departamento de Estudos Linguísticos e Literários (DELL), na Universidade Estadual do Sudoeste da Bahia (UESB). Apesar de se restringir a apenas um semestre de oferta, em um universo de quatro anos de curso, os resultados obtidos pelos alunos têm mostrado ser de grande valia para sua prática docente. Os tópicos debatidos em sala de aula dizem respeito a uma prática pedagógica focada nos princípios da função social da linguagem, algo relativamente novo para um grupo previamente exposto aos preceitos formais da 
Linguística Geral, mesmo em um curso de Formação de Professores, cujo objetivo principal é a preparação docente.

O conteúdo programático da LA, discutido em sala de aula, possui caráter interdisciplinar e está sempre buscando refletir sobre aspectos que dizem respeito ao hibridismo teórico e metodológico dessa área de estudo. Pensando dessa forma, são debatidos artigos teóricos e analisadas aplicações práticas de vários estudiosos, nacionais e internacionais, que se debruçam sobre essa grande área do saber, para nos proporcionar reflexão e reformulação de nossas bases epistemológicas e de nossa forma de conduzir pesquisas, cujos resultados possam ser transformados em ações práticas do cotidiano acadêmico.

Embora tenhamos o cuidado de sempre revisitar os cânones da LA, não nos furtamos, entretanto, de enfatizar renomados autores nacionais, que muito têm contribuído para o avanço epistemológico da LA no Brasil, fazendo jus, assim, às perspectivas da Epistemologia do Sul e, ao mesmo tempo, valorizando as múltiplas visões epistemológicas mundiais. É nesse contexto que uma das atividades exigidas para a integralização da disciplina diz respeito a uma entrevista escrita, feita pelos alunos, a um dos autores estudados durante o semestre. Desta vez, o pesquisador escolhido foi o professor Dr. Vilson José Leffa, cujos trabalhos no campo da LA, além de serem diversificados, convergem para uma reflexão efetiva da nossa prática pedagógica, um dos objetivos principais na formação docente, além de lidar com questões políticas e culturais relacionadas às abordagens empíricas e hermenêuticas da linguagem. Com isso, nossos alunos serão capazes de entender o ensino de línguas não apenas como um elemento discursivo, mas, também, como um agente de transformação social e de compreensão da realidade.

Portanto, gostaríamos de agradecer ao professor Leffa que, apesar de ter uma agenda extremamente ocupada, dispensou um pouco do seu valioso tempo para dialogar com os meus alunos e, consequentemente, com todos aqueles que vierem a ter acesso a esta entrevista.

Como podemos observar, as perguntas que seguem versam sobre os mais variados temas, dentro da Linguística Aplicada, e convergem para a prática docente, demonstrando, 
assim, grande preocupação e inquietação desses futuros professores de língua com seu fazer pedagógico.

Passemos, então, às questões dos alunos e às respostas do professor entrevistado.

\section{Entrevista}

Ana Claudia Oliveira Azevedo: Estudiosos como Corrêa Júnior (2018) aplicam ao ensino/aprendizagem de línguas o conceito de affordances, que diz respeito às oportunidades de ação que cada indivíduo encontra no ambiente em que está. Nessa perspectiva, o meio fornece diversas affordances, e cada pessoa as vê e se apropria delas de maneira particular, assim, é possível que recursos digitais criados para diversos fins passem a ser usados no intuito de aprender outra língua, por exemplo. Nesse sentido, de acordo com Corrêa Júnior (2018), na Linguística Aplicada, o conceito affordance seria importante "para entender os vínculos criados pelos sujeitos com a(s) língua(s) que aprende(m), bem como com as ferramentas utilizadas para essa finalidade" (CORREA-JUNIOR, 2018), uma vez que esses vínculos seriam diferentes para cada sujeito.

Considerando que as affordances se estendem às tecnologias, pode-se afirmar que redes sociais, como o Twitter, podem ser utilizadas para fins de aprendizagem de língua inglesa, apesar de não terem sido criadas para esse fim. O Twitter, rede social caracterizada pelos posts de 280 (antes 140) caracteres, tem sido objeto de algumas pesquisas sobre ensino/aprendizagem de língua inglesa, tais como as de Borau et. al (2009) - que analisa o uso do Twitter como ferramenta de prática da língua em um contexto de ensino a distância, destacando que o Twitter, por ser composto por mensagens curtas, pode ser usado por pessoas de diferentes níveis de conhecimento da língua inglesa - e de Araújo, Costa e Dieb (2011) - que analisam os tweets de um perfil voltado para a aprendizagem de inglês. Com base nessas considerações, questiono: De que forma a rede social Twitter, provavelmente já utilizada pelos alunos com outros objetivos, pode ser um affordance para a aprendizagem de leitura e escrita de inglês em um contexto de educação básica? Qual seria o papel do professor na mediação desse uso? 
Vilson Leffa: A aprendizagem de uma língua estrangeira nada tem a ver com a transmissão de conhecimento, às vezes típico da sala de aula, com o professor em pé falando para o aluno sentado na sua frente. A língua é basicamente uma habilidade que se adquire com a prática, não apenas ouvindo, não apenas lendo, mas também falando e escrevendo. Não basta receber a língua; é preciso, também, produzi-la. A aprendizagem de uma língua não é um processo isolado de aquisição, que se desenvolve de modo invisível na privacidade da mente do aluno; é um produto físico, que resulta de uma ação compartilhada, seja uma mensagem gravada no Whats $A p p$ ou um comentário escrito no Facebook, entre tantas possibilidades. A língua, por ser uma habilidade, mais do que um conhecimento, implica a prática da interação com o outro para ser desenvolvida.

Por uma grande coincidência, é exatamente isso que o aluno deseja quando tenta aprender a língua do outro. Certamente, não estará interessado em transformar frases afirmativas em negativas, preencher lacunas com a forma correta do verbo ou enumerar uma coluna pela outra, se ele minimamente não conseguir perceber a relevância desses exercícios para a prática autêntica da língua. O que ele realmente deseja é se engajar em atividades mais significativas como jogar games, ler sobre temas de seus interesses, assistir vídeos que fazem sua cabeça e, principalmente, trocar mensagens com um interlocutor de verdade.

O papel do professor não é ensinar a língua ao aluno no sentido de passar um conhecimento, mas de propiciar as condições para que o aprendiz possa usar a língua produtivamente, como um instrumento de comunicação para interagir com o outro. Antigamente, achar um interlocutor para o aluno era uma tarefa muitas vezes impossível para o professor, principalmente quando a escola ficava longe dos grandes centros. Atualmente, com os meios de comunicação de massa e as redes sociais como o Twitter e o Whats App, a interação com interlocutores autênticos, ficou muito mais fácil. É razoável esperar do professor que procure usar esses recursos em suas aulas.

Jamilly da Silva Oliveira: No livro Educação à Distância: a formação de comunidades virtuais de aprendizagem" (2013), o senhor, juntamente com Christiane Heemann, ao 
realizarem uma abordagem acerca da Teoria da Atividade, proposta por Vygotsky, Leontiev e Luria, afirmam que:

É típico do desenvolvimento das sociedades humanas as pessoas constantemente inventarem novas ferramentas para usarem em suas atividades; isso afeta a forma como as pessoas participam e agem na comunidade uma vez que as atividades são mediadas pelas ferramentas. As ferramentas afetam o modo como as pessoas operam sobre determinada tarefa e pode, por sua vez, afetar a própria tarefa (HEEMANN; LEFFA, 2013, p. 32).

Ler isso nos atenta para o fato de que algumas ferramentas, como o computador e o celular, ressignificaram o modo como os alunos aprendem e trouxeram inovações para a sala de aula. Podemos citar, por exemplo, o hábito que os alunos criaram de tirar fotografias do quadro no lugar de transcrever as informações no caderno, ou, ainda, os muitos aplicativos e sites que incitam a aprendizagem. Neste contexto, gostaria de saber o que o senhor considera como a mais significativa mudança advinda das modificações nas ferramentas de aprendizagem e o que elas implicarão no trabalho do professor.

Vilson Leffa: O ser humano possui várias características que o tornam único em relação às outras espécies, entre as quais eu destacaria a capacidade de transformar o mundo e de se transformar com ele, levando a um processo que normalmente chamamos de evolução. Ao contrário dos outros animais que, geração após geração, repetem rigorosamente os mesmos comportamentos que caracterizam sua espécie, o ser humano evolui de uma geração para outra. Em tom jocoso e sério ao mesmo tempo, podemos dizer que uma vaca, há mil anos atrás, agia do mesmo modo como age atualmente, caminhando, pastando e babando, sempre do mesmo jeito. Vamos falar sério: a vaca não tem a obrigação de evoluir, ao contrário do ser humano, que evoluiu muito nesses mil anos, por força das ferramentas que desenvolveu. $\mathrm{Na}$ verdade, mudou o mundo, mudou seu corpo, sua mente e a própria vaca, que foi confinada e inseminada artificialmente para produzir mais leite. Em resumo, 
criamos ferramentas que transformam o mundo, pessoas e animais - para o bem ou para o mal.

Hoje, temos ferramentas para tudo, inclusive para o ensino e aprendizagem de línguas, em números que podem chegar aos milhares de aplicativos se considerarmos as tecnologias digitais: há Apps para corrigir erros gramaticais, melhorar a pronúncia, desenvolver a compreensão oral, acelerar a leitura, assistindo, enfim, o aluno em todos os aspectos que afetam a aprendizagem de uma língua. Aprender uma língua, atualmente, com o advento das tecnologias digitais, é muito diferente da era pré-internet, com mudanças significativas principalmente naquelas questões que envolvem o tempo e o espaço. Em relação ao tempo, podemos optar por conversar com alguém de modo síncrono ou assíncrono, falando junto com o interlocutor ou gravando mensagens para serem ouvidas posteriormente. Em relação ao espaço, a distância praticamente deixou de existir, permitindo, por exemplo, que um estudante de inglês no Brasil pratique a língua com um colega do outro lado do planeta.

O trabalho do professor está sendo afetado por essas ferramentas, trazendo tanto benefícios como desafios que vão afetar sua zona de conforto. Vejo como benefício o aumento da ação pedagógica do professor, rompendo as barreiras do tempo e do espaço para chegar ao aluno na hora que lhe for mais conveniente e no lugar em que ele estiver. Usando a analogia do autor que se pluraliza em seus livros para chegar a inúmeros leitores, o professor se multiplica nas atividades que prepara e disponibiliza para seus alunos na internet. Este é o lado bom.

Do lado negativo, paira a ameaça de sobrecarga de trabalho para o professor. É óbvio que o professor não pode, e nem deve, trabalhar 24 horas por dia, 7 dias por semana. Não é nada aconselhável, por exemplo, criar um grupo de WhatsApp com os alunos de cada turma e depois responder individualmente a dúvidas de cada aluno de cada uma das turmas. É preciso tomar cuidado com a internet, porque ela amplia o tempo, somando o síncrono ao assíncrono, e compacta o espaço geográfico, tornando perto o que está longe. Criar um grupo com os alunos é criar uma comunidade de prática com regras que devem ficar bem claras, incluindo a gestão do tempo. 
João Pedro Santana Luciano da Silva: Segundo Cynthia D. Nelson, em "A teoria queer em linguística aplicada: enigmas sobre 'sair do armário' em sala de aulas globalizadas",

a pesquisa em linguísica aplicada (LA) e em educação sobre questões gays e lésbicas em geral e sobre questões relativas a 'sair do armário', em particular, têm cada vez mais se engajado com teorias pós-estruturalistas e queer de identidade (Brizmann, 1995; Pinas, 1998). Teoricamente, o foco mudou na direção de pensar as identidades sexuais como 'atos' em vez de como fatos e na direção de problematizar todas as identidades sexuais, em vez de considerar a liberação daquelas oprimidas (Butler, 1993; Warner, 1992) (NELSON, 2004, p. 216).

Com base em Nelson (2004) e ligando aos contextos emergentes que têm circundado a sociedade brasileira nos últimos meses do ano de 2018, pergunta-se: quais os possíveis impactos para a pesquisa em LA voltada às questões sobre gênero e sexualidade na escola, num período de tensão social e política em que há uma tentativa de "apagamento" da identidade do sujeito LGBT+?

Vilson Leffa: Eu sou daqueles que acham que as grandes obras da literatura e das artes em geral tendem a surgir com mais intensidade nos momentos de conflito, sejam os conflitos pessoais do artista ou as crises coletivas, provocadas, por exemplo, durante as ditaduras. Normalmente, no mundo da arte uma pessoa só consegue produzir uma obra de valor se estiver envolvida em um conflito que esteja tentando resolver. É possível que uma crise social acabe se somando ao conflito pessoal do artista, ampliando o conflito e propiciando um vigor maior à sua obra. É o que acontece, a meu ver, no mundo da arte, onde a existência desse conflito pode às vezes ser mais relevante para a qualidade da obra do que o patrocínio de um mecenas.

O mundo da ciência, em alguns aspectos, é semelhante ao mundo da arte: para avançar, precisa do conflito. Entendo que há aqui três estágios críticos que precisam ser vencidos para o desenvolvimento da ciência. No primeiro, e mais raso, o cientista não se 
dá conta da existência do conflito, homogeneizando as diferenças e naturalizando o que está errado como correto, numa atitude ingênua. No segundo estágio, ocorre a problematização, quando o cientista adquire consciência do conflito e consegue pelo menos descrevê-lo como ele realmente é. O terceiro e último estágio ocorre quando o pesquisador descobre que não basta descrever o conflito; é preciso resolvê-lo.

Uma diferença importante entre o mundo da ciência e o da arte é que, na ciência, os conflitos são mais de natureza coletiva do que pessoal. A pesquisa científica atual, pela sua complexidade, não tem mais condições de ser conduzida por um cientista que trabalhe isoladamente; é basicamente um trabalho de equipe, o que implica a necessidade de apoio, tanto de órgãos oficiais de fomento como até de entidades privadas, às vezes em forma de doações. Nesse contexto, temas de pesquisa que envolvam questões de gênero e sexualidade podem ser questionados e sofrer cortes na distribuição das verbas disponíveis, criando um impacto negativo. Não acredito, porém, que essas pesquisas estejam ameaçadas de extinção. É possível que a tentativa de extermínio acabe gerando a resistência dos pesquisadores e incentivando a luta pela relevância dessas áreas, resultando, quem sabe, em um trabalho superior ao que é feito em outras áreas mais agraciadas pelo apoio dos órgãos de fomento.

Lucas Viana Alencar: Sabe-se que a Língua Inglesa é vista, hoje, como uma ferramenta de acesso ao mundo (do entretenimento até dos negócios). Nessa perspectiva, muitos autores que atuam na área da Linguística Aplicada entendem que o Inglês passou a ser considerado como Língua Franca (Crystal, 1997); (Rajagopalan, 2003), o que comprova a importância e, ao mesmo tempo, o impacto positivo que o aprendizado de uma língua estrangeira - no caso, o Inglês - pode proporcionar ao indivíduo. Mesmo com todos os pontos positivos a favor da Língua Inglesa, vemos, no Brasil, uma realidade muito difícil de consolidar a aprendizagem de uma língua adicional como é apresentada nos PCN, pois os objetivos apresentados nos Parâmetros Curriculares Nacionais não são compatíveis com a realidade brasileira. Assim, o que temos são alunos com baixíssimo nível de proficiência 
em todas as habilidades (listening, speaking, reading, writing), inclusive na leitura, o que é algo preocupante, já que, para ter acesso ao nível superior, os alunos precisam passar por uma prova que analisará a leitura e interpretação de textos, como o ENEM e provas de vestibulares. Sobre a problemática levantada anteriormente, acrescento, ainda, outro desafio enfrentado pelo professor em sala de aula: a falta de interesse de leitura dos alunos, principalmente em outra língua. Dessa forma, apresento meu questionamento: Como garantir o ensino da habilidade da leitura em língua inglesa para alunos que não possuem a prática leitora nem em sua própria língua materna, o Português? Além disso, como garantir que esse processo seja algo útil não só para uma prova, mas para a vida deste aluno?

Vilson Leffa: $\mathrm{Na}$ minha opinião, há três culpados pelo fracasso do ensino do inglês na escola: o aluno, o professor e o governo. Se o aluno não tem o desejo de aprender, não lê em sua própria língua e está preocupado apenas em passar em uma prova de proficiência, sinceramente, não vejo como o professor possa garantir o desenvolvimento da habilidade da leitura. "Garantir" é também uma palavra muito forte. O que o professor pode fazer é propiciar condições para que o aluno aprenda, querendo. Se ele não tiver um desejo mínimo de aprender, não vejo como resolver o problema; nesse, com perdão da expressão, o buraco está mais embaixo.

Eu tenho por princípio não falar mal do professor, levado por várias razões: em primeiro lugar, sempre gostei dos professores que tive quando fui aluno; depois, descobri professores fantásticos quando trabalhei como formador de professores, tanto na educação inicial como na educação continuada; e, finalmente, quando me convenci, já chegando ao fim de minha carreira, de que ser professor de línguas é lidar com a essência do ser humano, porque é a língua que nos constitui. A culpa do fracasso do aluno pode ser, então, do professor, quando não se dá conta de seu valor.

Por fim, a culpa também pode ser do governo que nos representa, partindo do princípio nada delicado de que temos o governo que merecemos. Eu até acho que o governo, ao longo dos anos, tem se esforçado, incluindo um período em que concedeu 
milhares de bolsas de estudo para alunos da graduação fazerem estágio no exterior. O que faltou foi a continuidade de alguns projetos iniciados.

O problema é que não chegamos a resultado nenhum se ficarmos eternamente pondo a culpa no outro: não adianta o professor acusar o aluno de fazer de conta que estuda; o aluno acusar o professor de que faz de conta que ensina; e todos acusando o governo de que faz de conta que está preocupado com a educação. Acho que precisamos todos pegar juntos: aluno, professor e governo, começando por uma espécie de cumplicidade, no sentido positivo, entre professor e aluno.

Marcus Avelar Baleeiro do Rosário: De acordo com Dörnyei e Ushioda (2011), “o entusiasmo do professor e o seu comprometimento são um dos principais fatores que afetam a motivação do aluno a aprender”. Além disso, Venancio (2010) cita vários aspectos que desmotivam o professor, como a falta de crença do aluno na disciplina de língua inglesa, a desvalorização da disciplina pelos colegas de outras disciplinas, a crença de que a disciplina não reprova, o número excessivo de alunos, a falta de material didático, a falta de apoio da coordenação etc. Tendo em vista todos esses aspectos e obstáculos, como o professor de língua inglesa pode se manter motivado a continuar no exercício da docência e superar todas essas dificuldades? De que ponto o professor deve partir para motivar plenamente seus alunos e, consequentemente, se sentir motivado? Quais técnicas o professor poderia incluir em suas práticas de ensino para que essas dificuldades pudessem ser transpostas e esse objetivo pudesse ser alcançado?

Vilson Leffa: Vejo a aprendizagem como algo que vem de fora para dentro. O aluno aprende inglês, espanhol ou qualquer outra língua por exposição ao input, lendo e/ou ouvindo a língua ao redor de si. Esse input é mais produtivo quando vem de outras pessoas, com as quais o aluno pode interagir em situações autênticas de comunicação. O input pode vir, também, dos objetos que nos cercam, como livros, revistas, jornais, meios de comunicação de massa, smartphones, etc. Como disse John Dewey, famoso filósofo e pedagogo norte-americano do início do século XX: aprendemos com pessoas e objetos. 
O problema é que a aprendizagem depende de algo que vem de dentro do aluno, que é a motivação intrínseca, o desejo de aprender. Existe também, é claro, a motivação extrínseca, que vem de fora, mas que é apenas um desvio, uma espécie de refração da verdadeira motivação. Ganhar uma estrelinha do professor, uma bicicleta dos pais, uma boa nota na prova são todos desvios de motivação, provocados por uma ação externa, estranhas ao desejo interno de aprender.

Os gregos, para conquistar Troia, construíram um cavalo para penetrar na cidade. O professor, para motivar o aluno, precisa pensar grande, construir algum cavalo de Troia, e, depois, descobrir alguma brecha no aluno por onde possa penetrar e jogar lá dentro o vírus do desejo de aprender. É difícil, mas não impossível. A meu ver, os grandes mestres são aqueles que inspiram os alunos. Não precisa ser um guru para isso, nem um grande sábio, nem uma figura olímpica. Basta ser honesto, até para dizer que não sabe a resposta para uma pergunta; mas, também, se souber, responda, mostrando que sabe. Isso é ser honesto. Não podemos ir "de encontro a", mas "ao encontro de" quando estamos na frente do aluno.

Rossana Oliveira Reis: O estudo do uso das TIC (Tecnologias da Informação e Comunicação) em ambientes de aprendizagem tem se tornado cada vez mais frequente nos trabalhos acadêmicos que envolvem pesquisas em linguística aplicada e tecnologias. Muitos são os trabalhos que já apresentam considerações acerca do funcionamento das comunidades online como ambiente de interação e estudos. Sabendo disso, Preece (2001, apud LEFFA, 2013, p. 69) afirma que:

“[...]comunidade online é qualquer espaço social onde as pessoas se juntam para conseguir e dar informações ou apoio, para aprender ou para encontrar companhia; ou seja, é um grupo de pessoas que interage em um ambiente virtual. Para a autora, as comunidades online dependem de um objetivo, do software de apoio, do tamanho, da duração da sua existência, da cultura dos seus membros e de regras e normas que regem esta comunidade." (Preece, 2001, apud LEFFA, 2013, p. 69) 
A partir disso, e sabendo das discussões atuais que versam sobre o barateamento dos custos da educação, transformando-a em ensino a distância, é que pergunto: Quais as possíveis implicações que teria na educação de nível básico a redução das aulas presenciais a encontros no ambiente online?

Vilson Leffa: Eu cursei o ensino médio, fazendo um curso a distância, conhecido na época como "Curso por Correspondência", seguido de um exame feito em uma escola pública qualificada para esse tipo de avaliação. Como não havia escola de ensino médio onde eu morava e era obrigado a trabalhar, o curso a distância foi a única solução para me qualificar nesse nível de ensino. Mesmo beneficiado com essa solução, não sou a favor da educação a distância no nível básico, que vejo como um barateamento do ensino; esclarecendo, porém, que se eu tiver que escolher entre marginalizar o aluno do ensino médio, deixando-o sem acesso ao ensino presencial ou oferecer-lhe um ensino a distância pela internet, sou a favor da segunda opção. Eu sei que distanciar e marginalizar são sinônimos em alguns dicionários, mas, no meu caso, a aprendizagem a distância foi a única maneira de me aproximar da educação formal, uma oportunidade de inclusão.

Imaginemos dois extremos: de um lado, o ensino presencial como era feito na minha juventude, década de 1960, com os recursos típicos da época, incluindo professor, alunos, giz, livros e cadernos; do outro lado, o ensino a distância, como pode ser feito atualmente, com acesso livre à internet, incluindo recursos como o uso ilimitado de vídeos, redes sociais, games e aplicativos educacionais. Se fosse obrigado a escolher apenas um dos dois lados, eu sinceramente optaria pela internet e seus recursos. Ensinar não é controlar o aluno, mas propiciar a ele condições de aprendizagem. E isso a internet atual faz melhor do que a sala de aula do século passado.

Entendo que em um mundo ideal, a solução está no meio, reunindo o melhor dos dois mundos. No primeiro momento, o aluno estuda em casa, fazendo pela internet as atividades sugeridas pelo professor, incluindo vídeos, atividades interativas e até leitura de textos. No segundo momento, vai para a sala de aula, mostra o que fez, esclarece as dúvidas que ficaram, debate com professor e colegas. É o que se chama de sala de aula invertida. 
Outra possibilidade é o "Blended Learning", com diferentes formas de implementação, não necessariamente na ordem da sala de aula invertida, mas também reunindo atividades a distância e presenciais. Não vamos transformar os alunos nem em lobos solitários, escondidos atrás de monitores, sem oportunidade de socializar sua aprendizagem, nem em "Maria vai com as outras", socialmente afáveis, concordando com todos, mas incapazes de pensar diferente e ter opiniões próprias. $\mathrm{Na}$ dúvida entre presencial e a distância, fiquemos com os dois.

\section{Encerrando o diálogo}

Diógenes Cândido de Lima: A variedade de questionamentos aqui apresentados evidencia, de igual forma, a variedade do escopo das questões que abrangem a LA, uma área que vem buscando novas técnicas, novas abordagens e novas metodologias, no sentido de valorizar, ainda mais, as crenças e as experiências do professor de línguas, tornando-os profissionais mais críticos e reflexivos. Essa criticidade reflexiva é bem evidente nos questionamentos dirigidos ao professor Leffa e tão bem respondidos por ele.

Percebe-se uma grande preocupação, por parte desses futuros professores de língua, em se manterem atualizados, a fim de que possam desenvolver suas atividades de maneira competente, segura e responsável, no intuito de procurar fazer a diferença no desempenho de suas tarefas acadêmicas e profissionais.

Ademais, a diversidade de provocações trazidas pelos alunos entrevistadores demonstra seu interesse em procurar respostas para aquilo que não apenas eles, mas, também, "a sociedade precisa", conforme atesta o próprio Leffa. E a sociedade tem se beneficiado muito com as respostas dadas às questões da linguagem, por meio dos resultados das pesquisas em LA, principalmente por se tratar de uma área interdisciplinar, como bem comprovam as temáticas aqui tratadas. Foram trazidas para o debate uma multiplicidade de aspectos, incluindo os affordances, a influência das novas tecnologias no ensino de língua estrangeira e seus impactos para a pesquisa, motivação, aprendizagem das quatro 
habilidades, com ênfase na leitura, bem como questões de gêneros e sexualidade, tudo na perspectiva da formação docente do professor de línguas.

Esperamos que os insights apresentados nesta entrevista possam contribuir para a reflexão daqueles que lidam com o ensino e aprendizagem de línguas, em seus mais diversos aspectos.

\section{REFERENCIAS}

ARAÚJO, J. C.; COSTA, S. M.; DIEB, M. H. O Twitter e o Ensino de Língua Inglesa em 140 Caracteres. Educação \& Tecnologia, v. 16, p. 90-104, 2011.

BORAU, K. et. al. Microblogging for Language Learning: Using Twitter to train Communicative and Cultural Competence. International Conference on Web-Based Learning (ICWL) 2009: Advances in Web Based Learning - ICWL, 2009. p 78-87. Disponível em: https://link.springer.com/chapter/10.1007/978-3-642-03426-8_10.

CRYSTAL, D. English a s a global language. Cambridge: Cambridge University Press, 1997.

Dörnyei, Z.; Ushioda, E.Teaching and Researching: motivation (2nd ed.). Harlow: Longman. 2011.

GOMES JUNIOR, R. C.; TEIXEIRA, G. S.; SILVA, M. G.; PAULINO, C. A. Affordances de tecnologias digitais para o desenvolvimento de habilidades orais em inglês. Revista Brasileira de Linguística Aplicada, v. 18, p. 57-78, 2018.

HEEMAN, C.; LEFFA, V. J. Educação a Distância: a formação de comunidades virtuais de aprendizagem. Pelotas: EDUCAT, 2013.

NELSON, C. D. A teoria queer em Linguística Aplicada: enigmas sobre "sair do armário" em salas de aula globalizadas. In: MOITA LOPES, L. P. da. (Org.). Por uma Linguística Aplicada indisciplinar. São Paulo: Parábola Editorial, 2006, p.215-232.

RAJAGOPALAN, K. Por uma Linguística Crítica: Linguagem, identidade e a questão ética. São Paulo: Parábola, 2003.

VENÂNCIO, M. das G. C. C. Remotivação para aprender inglês. In: BARCELOS, A. M. F.; COELHO, H. S. H. (Orgs.). Emoções, reflexões e (trans)form(ações) de alunos, professores e formadores de professores de linguas. Campinas: Pontes, 2010. p. 227-247. 